\title{
Banana Peel as a Biosorbent in Removal of Nitrate from Water
}

\author{
Ch. Adisheshu Reddy ${ }^{1}$, N. Prashanthi ${ }^{2}$, P. Hari Babu ${ }^{3 *}$ Jyoti S Mahale ${ }^{4}$ \\ Department of Chemical Engineering, Rajiv Gandhi University of Knowledge Technologies (RGUKT), Basar, India ${ }^{1,2}$ \\ *Correspondence: Faculty, Department of Chemical Engineering, RGUKT, Basar, India ${ }^{3}$
}

\begin{abstract}
The contamination of water by nitrate is profound. Cost-effective and safe water treatment methods are required to remove nitrate from water. Biosorption is one of the methods which meet above objectives in addition to its other advantages like cheap adsorbents which can be reused, simple process with less wastage production and overall highly efficient. The present work studies the feasibility of use of banana peel as a Biosorbent in removal of nitrate from the drinking water. The effect of different parameters like contact time, adsorbent size fraction, adsorbent dosage, nitrate concentration was studied. The removal efficiency of nearly $80 \%$ was achieved when $0.05 \mathrm{~g}$ of banana peel powder of $106 \mu \mathrm{m}$ size fraction was used as adsorbent to treat $100 \mathrm{ml}$ of water sample of $200 \mathrm{mg} / \mathrm{l}$ nitrate concentration for a contact time of $0.5 \mathrm{~h}$
\end{abstract}

Keywords: Biosorbent, Adsorbent, Nitrate Concentration.

\section{INTRODUCTION}

This section comprises the importance of ground water and its characteristic composition and current scenario of ground water in India. It also gives an introduction into the ground water contamination in India and various districts of Telangana and Andhra Pradesh.

\subsection{GROUND WATER SCENARIO IN INDIA}

Ground water has become one of the important sources of water for meeting the requirements of various sectors in the country in the last few decades. It plays a vital role in India's economic development and in ensuring its food security. The rapid pace of agricultural development, industrialization and urbanization has resulted in the over exploitation and contamination of ground water resources in parts of the country, resulting in various adverse environmental impacts and threatening its long-term sustainability.

The ground water available in the country, in general, is potable and suitable for various usages. However, localized occurrence of ground water having various chemical constituents in excess of the limits prescribed for drinking water use has been observed in almost all the states. The commonly observed contaminants such as Arsenic, Fluoride and Iron are geogenic (occurring due to natural causes mainly through rock-water interaction), whereas contaminants such as nitrates, phosphates, heavy metals etc. owe their origin to various human activities including domestic sewerage, agricultural practices and industrial effluents [1].The factors that influence ground water quality are: local geology, land use, climatic conditions particularly pattern and frequency of rainfall and anthropogenic activities such as use of fertilizers and pesticides in agriculture, disposal of domestic sewage and industrial effluents and extent of exploitation of ground water resources.

The list of the chemical constituents present groundwater in varying proportions is given Table 1.1.

\subsection{WATER CONTAMINATION IN INDIA}

As per the eleventh five year plan document of India (2007-12), there are about 2.17 L quality affected habitations in the country with more than half affected with excess iron, followed by fluoride, salinity, nitrate and arsenic in that order.

\begin{tabular}{|c|c|}
\hline $\begin{array}{c}\text { Constituent } \\
\text { Classes }\end{array}$ & Constituents \\
\hline $\begin{array}{c}\text { Major } \\
\text { Constituents } \\
(1.0 \text { to } 1000 \\
\text { mg/L) }\end{array}$ & $\begin{array}{c}\text { Sodium, Calcium, Magnesium, } \\
\text { Bicarbonate, Sulphate, Chloride, } \\
\text { Silica }\end{array}$ \\
\hline $\begin{array}{c}\text { Secondary } \\
\text { Constituents(0. } \\
01 \text { to10.0mg/L) }\end{array}$ & $\begin{array}{c}\text { Iron, Strontium, Potassium, } \\
\text { Carbonate, Nitrate, Fluoride, } \\
\text { Boron }\end{array}$ \\
\hline $\begin{array}{c}\text { Minor } \\
\text { Constituents(0. } \\
0001 \text { to }\end{array}$ & $\begin{array}{c}\text { Antimony, Aluminium, Arsenic, } \\
\text { Barium, Bromide, Cadmium, } \\
\text { Chromium, Cobalt, Copper, } \\
\text { Germanium, Iodide, Lead, } \\
\text { Lithium, Manganese, } \\
\text { Molybdenum, Nickel, }\end{array}$ \\
& $\begin{array}{c}\text { Phosphate, Rubidium, Selenium, } \\
\text { Titanium, Uranium, Vanadium, } \\
\text { Zinc }\end{array}$ \\
\hline $\begin{array}{c}\text { Trace } \\
\text { Constituents } \\
\text { generally less }\end{array}$ & $\begin{array}{c}\text { Beryllium, Bismuth, Cerium, } \\
\text { Cesium, Gallium, Gold, Indium, } \\
\text { Lantham, Niobium, Platinum, }\end{array}$ \\
\hline
\end{tabular}

Table 1.1: Major, minor and trace constituents of ground water [1]

The most widespread contamination in India is that of elevated levels of fluoride. It is widely prevalent in different parts of India, particularly in the state of Andhra in Pradesh, Tamilnadu, Uttar Pradesh, Gujarat, and in Rajasthan, where $50-100 \%$ of the districts have drinking water sources containing excess level of fluoride. As per 
an estimate (FRRDF, Fluorosis Research and Rural Development Foundation-1999) about 66 million people in India are consuming water with fluoride level beyond the permissible limit.

Table 1.2: Districts of Telangana and Andhra Pradesh with contaminants beyond permissible limits

\begin{tabular}{|c|c|c|}
\hline $\begin{array}{l}\text { S. } \\
\text { No }\end{array}$ & Contaminant & $\begin{array}{l}\text { Parts of district having } \\
\text { concentrations more in } \\
\text { permissible levels }\end{array}$ \\
\hline 1 & $\begin{array}{l}\text { Fluoride } \\
(>1.5 \mathrm{mg} / \mathrm{l})\end{array}$ & $\begin{array}{l}\text { Adilabad, Anantpur, Chittoor, } \\
\text { Guntur, Hyderabad, Medak, } \\
\text { Karimnagar, Ranga Reddy, } \\
\text { Khammam, Krishna, Kurnool, } \\
\text { Mahbubnagar, Nalgonda, } \\
\text { West Godavari, Warangal, } \\
\text { Nellore, Prakasam, } \\
\text { Visakhapatnam, Vizianagaram }\end{array}$ \\
\hline 2 & $\begin{array}{l}\text { Iron }(>1 \\
\mathrm{mg} / \mathrm{l})\end{array}$ & $\begin{array}{l}\text { Adilabad, Chittoor, Cuddapah, } \\
\text { Guntur, Hyderabad, } \\
\text { Karimnagar, Krishna, } \\
\text { Kurnool, Mahbubnagar, } \\
\text { Medak, Nalgonda, Nellore, } \\
\text { Nizamabad, Ranga Reddy, } \\
\text { Visakhapatnam }\end{array}$ \\
\hline 3 & $\begin{array}{l}\text { Nitrate } \\
(>45 \mathrm{mg} / \mathrm{l})\end{array}$ & $\begin{array}{l}\text { Adilabad, Anantpur, Chittoor, } \\
\text { Cuddapah, East Godavari, } \\
\text { Guntur, Hyderabad, Medak, } \\
\text { Warangal, Karimnagar, } \\
\text { Khammam, Krishna, Kurnool, } \\
\text { Mahbubnagar, Nalgonda, } \\
\text { Nellore, Nizamabad, } \\
\text { Prakasam, Ranga Reddy, } \\
\text { Srikakulam, Visakhapatnam, } \\
\text { Vizianagaram, West Godavari }\end{array}$ \\
\hline 4 & $\begin{array}{l}\text { Chloride } \\
(>1000 \mathrm{mg} / \mathrm{l})\end{array}$ & $\begin{array}{l}\text { E-Godavari, Prakasam, } \\
\text { Nellore, Guntur, Medak, } \\
\text { Mahbubnagar, Kurnool, } \\
\text { Nalgonda, Kadappa, Krishna, } \\
\text { Khammam, Warangal, } \\
\text { Srikakulam }\end{array}$ \\
\hline 5 & $\begin{array}{l}\text { Salinity } \\
(\mathrm{EC}>3000 \mu \mathrm{S} / \\
\mathrm{cm})\end{array}$ & $\begin{array}{l}\text { Anantapur, Chittoor, Kurnool, } \\
\text { Kadapa(Cuddapah), Nellore, } \\
\text { Prakasam, Guntur, Medak, } \\
\text { Mahbubnagar, Nalgonda, } \\
\text { Krishna, Khammam, } \\
\text { Warangal, East Godavari, } \\
\text { Srikakulam, Visakhapatnam }\end{array}$ \\
\hline
\end{tabular}

The next important contamination is arsenic in terms of its carcinogenic nature and number of persons residing in the risk zone. Geographically large areas affected by arsenic contamination are from West Bengal and Bihar. Besides, arsenic affected alluvial aquifers are reported from Uttar Pradesh, and sporadically from Jharkhand, Haryana, Punjab, Manipur and Assam.

Salinity does not cause serious health effects as compared to other geogenic contaminants. It is distributed mainly in western, north-western and southern part of India. The states largely affected by it are Rajasthan, Gujarat and Haryana. Besides, salinity originated from saline-water intrusion in coastal areas due to over pumping of groundwater in various scales and has been reported in the states of Tamilnadu, West Bengal, Orissa, Gujarat and Andhra Pradesh.

Nitrate, the end products of the biologic nitrification process, is the most ubiquitous chemical contaminant in the world's aquifers and the concentration levels are increasing. The distribution of NO3 in groundwater is controlled by a number of factors. They include source availability, thickness, precipitation, irrigation, ground water flow, aquifer heterogeneity, dissolved oxygen concentrations and electron donor availability and dispersion. Examples of nitrogen compounds found in naturally occurring waters include ammonia (NH3), nitrite (NO2-), nitrate (NO3-), and the ammonium ion (NH4+). Nitrogen is also found in many organic compounds such as proteins and protein derivatives including purines, pyrimidines, and urea. Generally, inorganic nitrogen salts are quite soluble in natural waters

Iron and manganese have got similar hydro geochemistry. Both of them are found in widely distributed geographical areas. Elevated iron has been reported from almost all states, covering almost all Principal Aquifer Systems. Elevated levels of $\mathrm{Mn}$ are sporadic in nature in comparison to Fe. Elevated level of Mn has been reported mainly from West Bengal, Tamil Nadu, Orissa, UP and Bihar.

\subsection{Contaminants}

This section consists of different contaminants their occurrence, health hazards and remedial measures to control them. A focus is laid on the contaminants more prevalent in the states of Telangana and Andhra Pradesh. Table 1.2 gives the information about the different districts where major contaminants like fluoride, iron, nitrate and chloride are present beyond the permissible limits.

\section{LITERATURE REVIEW}

\subsection{MUSA SAPIENTUM (BANANA) PEELS COMPOSITION}

Musa sapientum which is commonly called banana is a herbaceous plant of the family Musaceae. It is known to have originated from the tropical region of Southern Asia. The Musa sapientum grows up to a height of about $2-8 \mathrm{~m}$ with leaves of about $3.5 \mathrm{~m}$ in length. The stem which is also called pseudostem produces a single bunch of banana before dying and replaced by new pseudostem. The fruit grows in hanging cluster, with twenty fruits to a tier and 3 - 20 tiers to a bunch. The fruit is protected by its peel which is discarded as waste after the inner fleshy portion is eaten [2].

Musa sapientum fruits have been reported to prevent anaemia by stimulating the production of haemoglobin in the blood. Its role to regulate blood pressure has been associated with the high content of potassium. Banana helps in solving the problem of constipation without necessary resorting to laxatives. It was reported that Banana can cure heart burns stress, strokes, ulcers and many other ailments. The peels have been reported to be useful in making banana charcoal, an alternative source of cooking fuel in Kampala. Besides this peels in conjunction 
with other substances create a liniment for reducing the acuteness of the arthritis aches and pains [2].

The concentration $(\mathrm{mg} / \mathrm{g})$ of potassium, calcium, sodium, iron, manganese, bromine, rubidium, strontium, zirconium and niobium are reported to be 78.10, 19.20, 24.30, 0.61, $76.20,0.04,0.21,0.03,0.02$ and 0.02 respectively. The percentage concentrations of protein, crude lipid, carbohydrate and crude fibre were $0.90,1.70,59.00$ and 31.70 respectively [2].

\subsection{Removal of Contaminants by Banana Peel}

It was reported that the maximum percentage removal of As (III) ion by banana peel was $82.23 \%$ at $0.843 \mathrm{mg} / \mathrm{g}$ uptake capacity, $\mathrm{pH}$ of 7 , dosage of $8 \mathrm{~g}$, contact time of 90 minutes and reaction temperature of $35^{\circ} \mathrm{C}$, respectively [3].

The removal efficiencies of fluoride by banana peel (at $\mathrm{F}$ concentration of $20 \mathrm{mg} / \mathrm{l}$ contact time $60 \mathrm{~min} \mathrm{pH}=6$ ), groundnut shell and sweet lemon peel were reported as $94.34,89.9$ and $59.59 \%$ respectively [4].

The removal efficiency of banana peel in removal of various other contaminants is shown in Table 1.3

Table 1.3: The efficiency of adsorption by banana peel

\begin{tabular}{|l|l|l|}
\hline Constituent & $\begin{array}{l}\text { Removal Efficiency/ } \\
\% \text { Adsorption }\end{array}$ & Reference \\
\hline Chromium & 95 & {$[7]$} \\
\hline Iron & 100 & {$[5]$} \\
\hline Cobalt & 81 & {$[4]$} \\
\hline Nickel & 74 & {$[4]$} \\
\hline Zinc & 90.5 & {$[6]$} \\
\hline
\end{tabular}

Biosorbent is a bio-mass which is used as adsorbent. The need for cost-effective and efficient water treatment methods increased the interest in biosorbents and banana peel is one of them

\section{MATERIALS AND METHODS}

\subsection{PREPARATION OF ADSORBENT (BANANA PEEL POWDER)}

Banana peels collected from institute (RGUKT) Mess, were cleaned and dried under sun for 3 days. The dried peels were grounded to powder and sieved. The powder on the meshes of size 53, 75, 106 and $150 \mu \mathrm{m}$ was collected separately.

\subsection{Preparation OF Nitrate SaMPle}

Anhydrous and pure Potassium Nitrate $\left(\mathrm{KNO}_{3}\right)$ was used as a source of nitrate. All experiments were carried with water sample of $200 \mathrm{mg} / \mathrm{l}$ nitrate concentration which was prepared by dissolving nearly $0.033 \mathrm{~g}$ of $\mathrm{KNO}_{3}$ in $100 \mathrm{ml}$ water.

\subsection{EFFECT OF CONTACT TIME}

$0.1 \mathrm{~g}$ of banana peel was taken in $100 \mathrm{ml}$ of nitrate sample and was allowed for stirring for different time periods of $0.5,1,1.5,2,3$ hours at a speed of $120 \mathrm{rpm}$ on an orbital shaker. The solution is filtered and adsorbent is separated from the treated nitrate sample.

\subsection{EFFECT OF SIZE FRACTION}

$0.1 \mathrm{~g}$ of four size fractions of banana peel powder which were prepared as mentioned in materials section were taken in nitrate sample and kept under continuous stirring for $0.5 \mathrm{hr}$

\subsection{EFFECT OF ADSORBENT DOSAGE}

The effect of adsorbent dosage is studied by varying adsorbent weight. $0.025,0.05,0.1,0.2,0.3 \mathrm{~g}$ of banana peel powder was taken in nitrate sample and allowed for stirring for a duration of $0.5 \mathrm{hr}$

\subsection{EFFECT OF Nitrate CONCENTRATION}

The effect of nitrate concentration is studied by varying nitrate concentration in the nitrate sample. Nitrate samples of nitrate concentration $60,75,100,150,200,250,300$ $\mathrm{mg} / \mathrm{l}$ nitrate were prepared and $0.1 \mathrm{~g}$ of adsorbent was taken and stirred for $0.5 \mathrm{~h}$.

\subsection{Calibration Of Nitrate STANDaRd CURVE}

Stock solution of nitrate concentration $10 \mu \mathrm{g} / \mathrm{ml}$ was prepared and it is diluted to obtain nitrate concentrations of $0.2,1,2,3,4,5 \mu \mathrm{g} / \mathrm{ml}$. The absorbance values were taken at a wavelength of $220 \mathrm{~nm}$ in UV-Visible spectrophotometer and a graph of absorbance and nitrate concentration was drawn. This was taken as standard curve and used for the entire study to detect nitrate in the water after adsorption.

\subsection{DETECTION OF NITRATE}

The solutions of all the above experiments were filtered and diluted to bring them into the concentration range of standard curve. The absorbance of diluted sample was taken at $220 \mathrm{~nm}$ in UV-Visible spectrophotometer. The concentration corresponding to the measured absorbance was read from the standard curve and removal efficiency was found out using the equation

$$
\text { Removal Efficiency }=\left(\left(\mathrm{C}_{0}-\mathrm{C}_{1}\right) / \mathrm{C}_{0}\right) * 100
$$

Where, $\mathrm{C}_{0}=$ Initial nitrate concentration, $\mathrm{C}_{1}=$ Nitrate concentration in water after adsorption

\subsection{CHARACTERIZATION OF ADSORBENT}

The morphology of banana peel was determined by using Scanning Electron Microscopy (SEM) and is summarized in results and discussions.

\section{RESULTS AND DISCUSSIONS}

\subsection{Nitrate STANDARd CURVE}

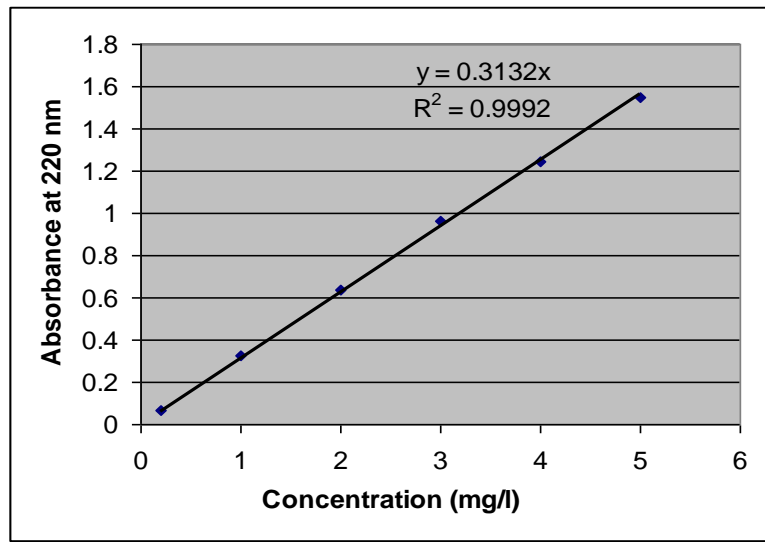

Fig 4.1 Nitrate Standard curve 
The nitrate standard curve is drawn as described in section 3 and is presented in fig 4.1. The data taken is the average of values of 3 experiments conducted separately.

\subsection{EFFECT OF CONTACT TIME}

The effect of contact time on removal efficiency is presented in fig 4.2 for different time periods of $0.5,1,1.5$, 2, 3 hours. The highest efficiency of nearly $79 \%$ was observed for contact time of $0.5 \mathrm{~h}$; however the removal efficiency for contact time of $1 \mathrm{~h}$ was also nearly the same. The removal efficiency for contact time of 1.5, 2, 3 hours were nearly same and equal to $78 \%$ approximately. Hence Contact time of $0.5 \mathrm{~h}$ was selected as optimum contact time and used for all the other experiments.

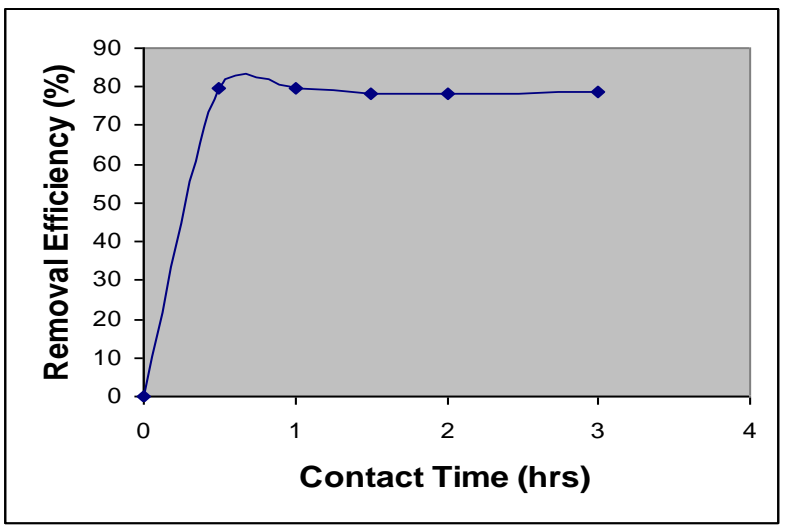

Fig 4.2 Effect of contact time of adsorbent on removal efficiency of nitrate

\subsection{EFFECT OF SIZE FRACTION}

The effect of size fraction on removal efficiency is shown in fig 4.3. The efficiency increased with size fraction with a highest efficiency when banana peel powder on $106 \mu \mathrm{m}$ mesh was used as adsorbent and decreased with further increase in size to $150 \mu \mathrm{m}$

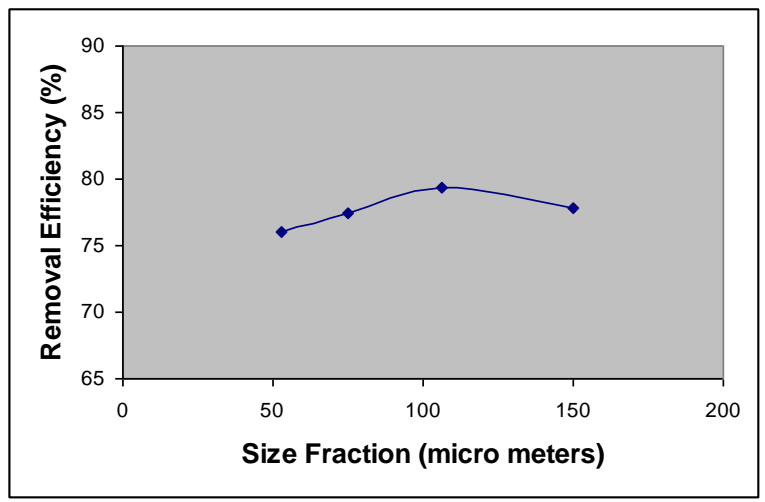

Fig 4.3 Effect of size fraction of adsorbent on removal efficiency of nitrate

\subsection{EFFECT OF ADSORBENT DOSAGE}

The effect of adsorbent dosage of banana peel powder on nitrate removal efficiency is shown in fig. The removal efficiency increased when adsorbent dose was increased from $0.025 \mathrm{~g}$ to $0.05 \mathrm{~g}$ where it was maximum and remained nearly same at $0.1 \mathrm{~g}$ dosage and decreased with further increase of dosage to 0.2 and $0.3 \mathrm{~g}$, however the difference was not more than $3 \%$.

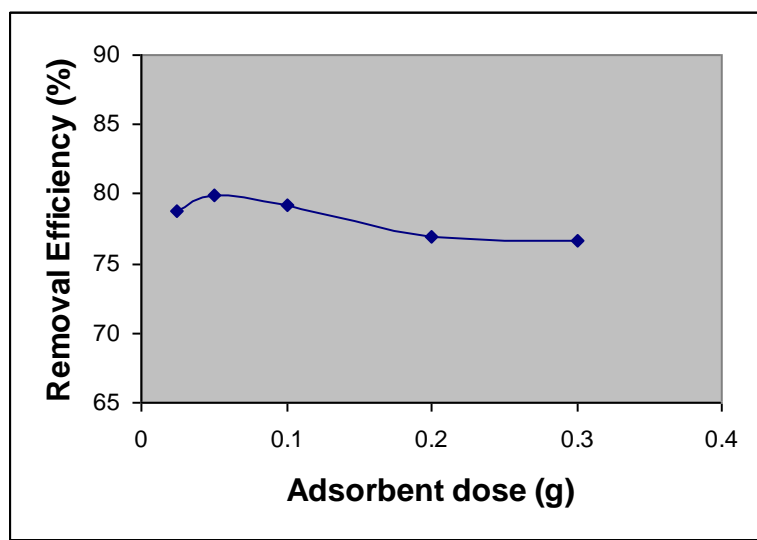

Fig 4.4 Effect of adsorbent dosage on removal efficiency of nitrate

\subsection{EFFECT OF NITRATE CONCENTRATION}

The nitrate removal efficiency of banana peel increased with increase in initial nitrate concentration. The increase in removal efficiency is a result of increase in nitrate ions in the solution which compete and adsorb to most of the sites present on the adsorbent.

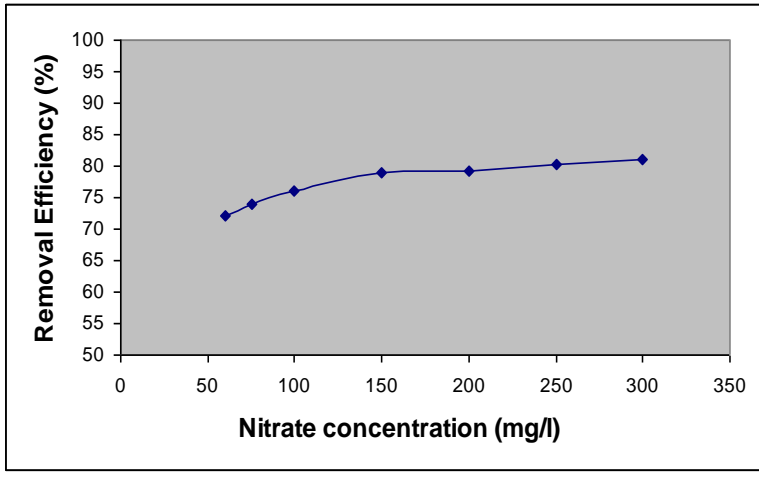

Fig 4.5 Effect of nitrate concentration on removal efficiency of nitrate

\subsection{SEM ANALYSIS}

Scanning Electron Microscopy (SEM) images as showed in fig 4.6.a-c shows the rough surface of banana peel and presence of voids.

a)

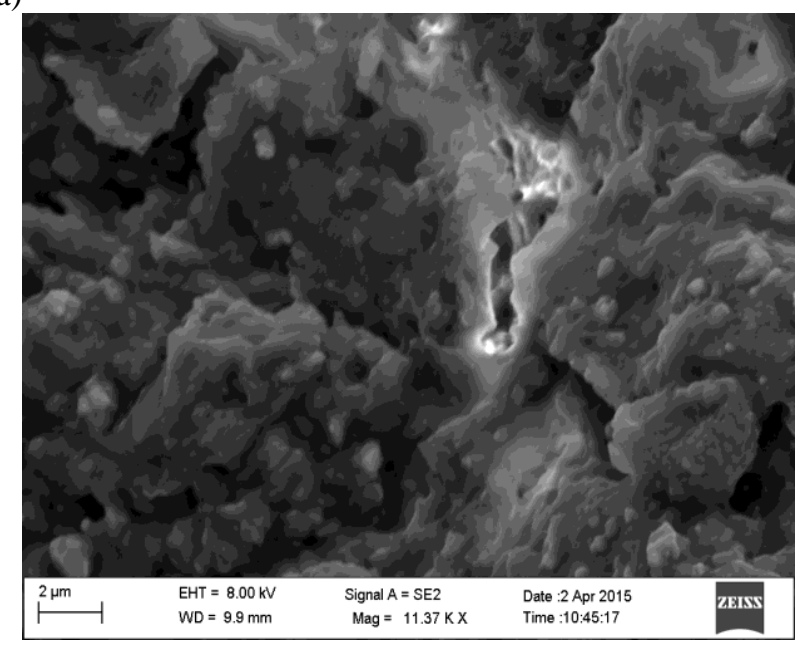


b)

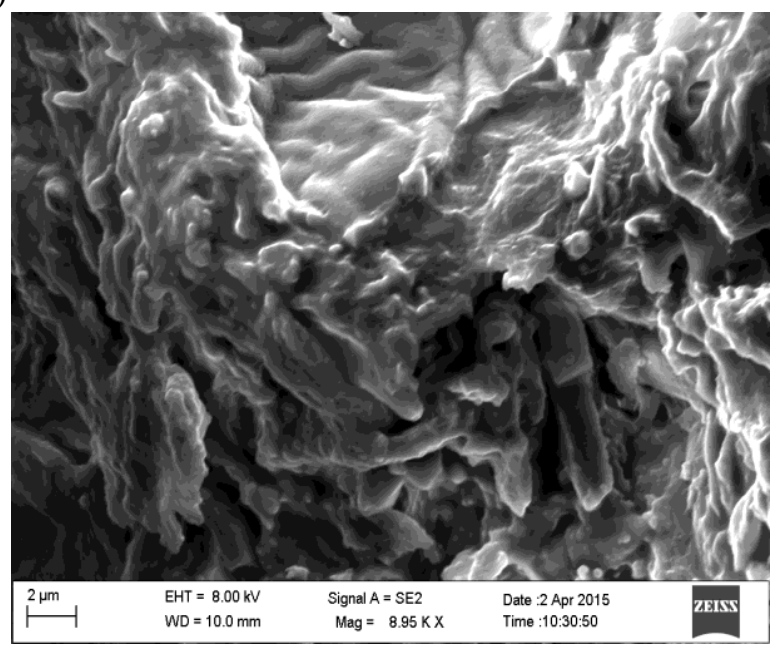

c)

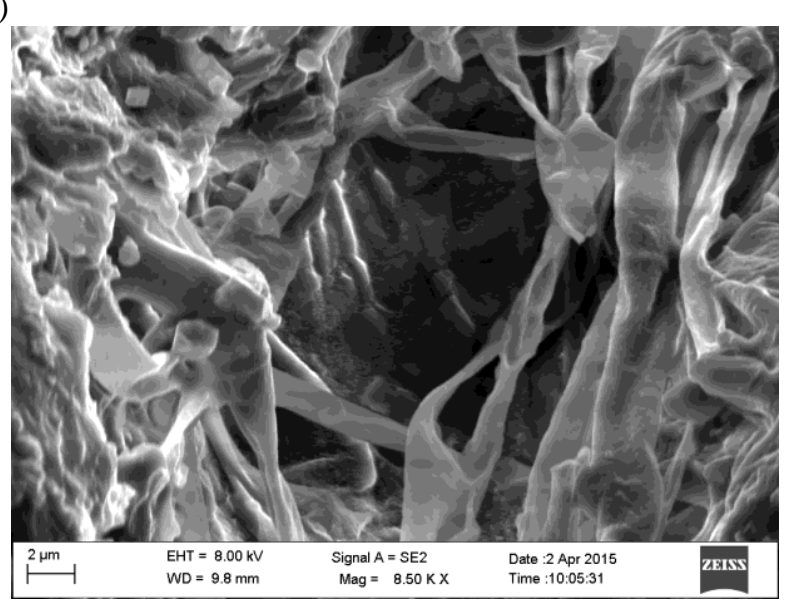

Fig 4.6.a-c Scanning Electron Microscopy (SEM) Images of Banana peel before adsorption

\section{CONCLUSIONS AND FUTURE WORK}

The contamination of nitrate in water is profound and emerging technologies are required for removal of it. The present study shows that banana peel can act as an efficient Biosorbent in removal of nitrate from water. The effect of different parameters like contact time, adsorbent size fraction, adsorbent dosage, nitrate concentration was studied. The removal efficiency of nearly $80 \%$ was achieved when $0.05 \mathrm{~g}$ of banana peel powder of $106 \mu \mathrm{m}$ size fraction was used as adsorbent to treat $100 \mathrm{ml}$ of water sample of $200 \mathrm{mg} / \mathrm{l}$ nitrate concentration for a contact time of $0.5 \mathrm{~h}$. Further study of effect of parameters like $\mathrm{pH}$, temperature and effect of different pre-treatment methods of adsorbent would help to increase the efficiency of nitrate removal and enhance the applicability of banana peel as a biosorbent.

\section{REFERENCES}

[1] Concept Note on GEOGENIC CONTAMINATION OF GROUND WATER IN INDIA with a special note on Nitrate - Central Ground Water Board Ministry of Water Resources Govt. of India (2014)

[2] Anhwange, B.A. J. Ugye, T.D. NyiaAtagher Chemical Composition of Musa Sapientum (Banana) PeEls. EJEAFChe, 8 (6), 2009. [437-442]

[3] Suantak kamsonlian, Chandrajit Balomajumder and Shri Chand (2012) A potential of biosorbent derived from banana peel for removal of As(III) from contaminated water ..Int. J. Chem. Sci. 3: 269-275.

[4] Zahra Abbasi1, Mohammad Alikarami (2013). Adsorptive Removal of $\mathrm{Co} 2+$ and $\mathrm{Ni2}+$ by Peels of Banana from Aqueous Solution. Universal Journal of Chemistry 1(3): 90-95.

[5] Aash Mohammad, CB Majumder (2014). Removal of Fluoride from Synthetic Waste Water By using Bio-Adsorbents. IJRET 4.

[6] Sunil Rajoriya, Balpreet kaur (2014). Adsorptive Removal of Zinc from Waste Water by Natural Biosorbents. IJESI 3: 60-80.

[7] Jamil R. Memon, Saima Q. Memon (2008). Banana Peel: A Green and Economical Sorbent for $\mathrm{Cr}(\mathrm{III})$ Removal. Pak. J. Anal. Environ. Chem. 9: $20-25$. 